\title{
The Prevalence and Characteristics of Bacteria Causing Acute Diarrhea in Korea, 2012
}

\author{
Nan-Ok Kim', Injun Cha', Jae-Seok Kim², Gyung Tae Chung', Yeon-Ho Kang', Sahyun Hong ${ }^{1}$ \\ ${ }^{1}$ Division of Enteric Diseases, Korea National Institute of Health, KCDC, Cheongwon, \\ ${ }^{2}$ Department of Laboratory Medicine, Hallym University College of Medicine, Seoul, Korea
}

Background: Through change in the climate and living environment, bacterial pathogens that cause diarrhea also change. This study sought to determine the characteristics of pathogens according to species, isolated region, and patient age/sex using National Surveillance Data for diarrhea, and to provide basic data for the prevention of diarrheal disease. Methods: From January to December 2012, stool specimens were collected from 21,180 diarrheal patients in Korea to identify the pathogenic bacteria involved. Pathogenic bacteria were analyzed according to isolated region and patient age/sex. Identification and analysis of the pathogens were conducted based on the Guidelines of the National Institute of Health Diagnostic Laboratory: Disease-specific protocol (2005).

Results: Among the 21,180 stool specimens, pathogenic bacteria known to cause diarrhea were isolated from 2,444 stool specimens $(11.5 \%)$. The isolation rate was highest in the summer (from June to September) for most pathogenic bacteria, except Escherichia coli, Staphylococcus aureus, and Clostridium perfringens. The isolation rate of pathogenic bacteria based on patient age was highest in children under the age of 10 .

Conclusion: Hygiene education should be addressed in diarrheal disease-susceptible groups, such as children under 10 , people in their 50 s, and those greater than 70 years old, and ongoing monitoring for pathogens is needed. In addition, an efficient information system and surveillance program should be continued for infection prevention. (Ann Clin Microbiol 2013;16: 174-181)

Key Words: Diarrhea, EnterNet, Surveillance, Pathogen

\section{INTRODUCTION}

급성설사질환은 전 세계적으로 매년 30-50억 건 이상 발생하 며, 약 200만 명의 환자가 사망에 이르는 것으로 보고되고 있다 [1-3]. 급성설사질환의 공중보건학적인 중요성으로 인해 급성 설사질환에 대한 실험실 감시는 다른 질환에 비해 우선적으로 실시되었으며, 대다수 국가에서 설사질환 관련 감시사업을 수 행하고 있다. 유럽연합은 36개국의 국가표준실험실(National Reference Lab)이 참여하는 엔터넷(EnterNet)을 운영하고 있고 [4], 미국과 호주에서는 식품매개질환에 대한 감시체계로 각각 푸드넷(FoodNet)과 오즈넷(OzFoodNet)을[5,6], 캐나다에서는 전 체 인구를 대상으로 하는 NESP (National Enteric Surveillance Program)와 지역 거점 중심의 C-EnterNet이 유기적으로 운영되 고 있다[7]. 일본에서는 국립감염병연구소(National Institute of
Infectious Diseases)가 중심이 되어 병원체 검출 정보 자료를 생산하고 있다.

국내에서는 1972년부터 전국 보건소와 시·도 보건환경연구 원, 질병관리본부 실험실을 연계한 급성 설사 질환 원인병원체 에 대한 검사 업무를 수행하였으며, 2001년부터는 능동적인 실 험실 감시시스템을 구축하였다. 2003년부터는 급성설사질환 실험실 감시사업(엔터넷, EnterNet-Korea)을 수행하고 있으며, 2008년 이후 대상 병원체의 확대, 보고주기, 결과 환류 및 관련 정보 제공주기 단축 등 다양한 방면으로 감시사업을 개선하였 으며, 2010년부터는 주 단위 보고체계를 구축하여 유관 기관에 국내 설사질환 발생 경향에 대한 자료를 주기적으로 제공하고 있다. 급성설사질환 실험실 감시 사업은 국가 감시사업으로서 전국병원에서 설사환자의 검체와 임상자료를 수집하고 보건환 경연구원에서 원인병원체에 대한 검사를 실시하며, 국립보건

Received 9 August, 2013, Revised 5 November, 2013, Accepted 15 November, 2013

Correspondence: Sahyun Hong, Division of Enteric Diseases, Korea National Institute of Health, KCDC, 187 Osongsaengmyeong2(i)-ro, Osong-eup, Cheongwon 363-951, Korea. (Tel) 82-43-719-8115, (Fax) 82-43-719-8149, (E-mail) strepto13@hanmail.net

(c) The Korean Society of Clinical Microbiology.

(a) This is an Open Access article distributed under the terms of the Creative Commons Attribution Non-Commercial License (http://creativecommons.org/licenses/by-nc/3.0) which permits unrestricted non-commercial use, distribution, and reproduction in any medium, provided the original work is properly cited. 
원에서 결과를 종합 분석하여 설사질환의 유행 양상 및 병원체 정보를 공개하고 있다.

저자들은 2012년도의 급성설사질환 실험실 감시사업을 통해 확인된 설사유발 원인 세균의 분리 현황 및 특성을 파악하고자 하였고, 앞으로 급성설사질환 관리를 위한 기초자료로 활용하 고자 하였다.

\section{MATERIALS AND METHODS}

\section{1. 검체 및 대상 균주}

전국 17 개 시·도 보건환경연구원과 106 개의 협력병원이 참 여하여 2012년도 한 해 동안 급성설사질환 실험실 감시사업을 통해 접수된 설사 환자의 분변검체를 대상으로 선택감별 배양 및 생화학적인 실험 기법을 이용하여 세균을 분리 동정한 후 그 결과를 설사질환 실험실 감시사업 자료로 수집하였다. 대상 균주는 설사를 유발하는 주요 세균성 병원체 10개 속(genus)으 로 Salmonella spp., pathogenic Escherichia coli (enterohemorrhagic E. coli; EHEC, enterotoxigenic E. coli; ETEC, enteropathogenic E. coli; EPEC, enteroinvasive E. coli; EIEC, enteroaggregative E. coli; EAEC), Campylobacter spp., Vibrio parahaemolyticus; V. parahaemolyticus, Shigella spp., Clostridium perfringens, Staphylococcus aureus, Bacilllus cereus, Listeria monocytogenes, Yersinia enterocolitica를 대상으로 하였다.

\section{2. 원인 병원체의 분리 동정}

급성설사질환을 유발하는 것으로 알려진 각 균 속의 주요 혈 청형 및 독소형을 대상으로 검사를 진행하였다[8]. Salmonella spp.와 Shigella spp.의 경우 검체를 MacConkey 배지에 배양한 다음, 의심되는 집락을 tryptic soy agar (TSA)에 계대하여 자란 집락을 API 20E kit (bioMerieux, Marcy I'Etoile, France)를 이용 하여 Salmonella spp. 또는 Shigella spp.를 확인하였다. Salmonella spp.는 생화학 동정이 완료된 후, $\mathrm{O}$ 항원과 $\mathrm{H}$ 항원에 대한 응집 반응을 통해 혈청형까지 확인하였으며[9], Shigella spp.는 O항 원 혈청형까지 확인하였다. Pathogenic E. coli는 PCR기법으로 EHEC는 stx $1, s t x 2, \mathrm{ETEC}$ 는 $l t, s t h, s t p, \mathrm{EPEC}$ 는 eaeA, $b f p A$, $\mathrm{EIEC}$ 는 $i \mathrm{paH}$, 그리고 $\mathrm{EAEC}$ 는 $a g g R$ 병원성 유전자를 확인하 였다. V. parahaemolyticus의 분리를 위해서는 검체를 thiosulfate citrate bile salts sucrose (TCBS) 배지에 배양한 후, TSA에 계대하여 자란 집락을 API 20E kit (bioMerieux)를 이용하여 동 정하였다. Campylobacter spp.의 경우 항생제가 첨가된 mCCDA (modified Charcoal Cefoperazone Deoxycholate Agar) 배지에 접종하여 미호기성 조건 $\left(5 \% \mathrm{O}_{2}, 10 \% \mathrm{CO}_{2}, 85 \% \mathrm{~N}_{2}\right)$ 으로 $42^{\circ} \mathrm{C}$ 에서 48시간 배양한 후, API CAMPY kit (bioMerieux)를 이용 하여 생화학 동정 및 $\mathrm{WHO}$ 에서 제시한 $\mathrm{PCR}$ 기법을 통해 분자 생물학적 동정을 하였다. C. perfringens는 tryptose sulfite cy- closerine (TSC) 배지에 배양하여 $37^{\circ} \mathrm{C}$ 에서 24 시간 혐기조건으로 배양한 다음, 전형적인 집락을 선택하여 API 20A kit (bioMerieux) 와 PCR기법을 이용하여 생화학적으로 C. perfringens이며 $c p a$ 와 $c p e$ 혹은 $c p a$ 와 $c p b 2$ 유전자가 확인된 균주를 최종 동정하 였다. S. aureus의 경우, mannitol salt agar (MSA)에 $37^{\circ} \mathrm{C}$ 에서 24시간 배양한 다음 황색 집락을 선별하여 TSA에 계대배양한 후, API Staph kit (bioMerieux)를 이용하여 동정하였다. 동정된 균주들에 대해 장독소 생산을 확인하기 위하여 $\mathrm{PCR}$ 을 이용하 여 sea, seb, sec, see 유전자들의 보유 여부를 확인하여, 한 개 이상의 유전자가 확인된 균주로 최종 동정하였다. B. cereus는 mannitol egg yolk polymyxin (MYP) 배지에 접종하여 $37^{\circ} \mathrm{C}$ 에 서 24시간 배양한 후 혼탁한 환을 갖는 분홍색 집락을 선별하 여 TSA에 계대한 후, API 50 CHB kit (bioMerieux)를 이용하 여 생화학적으로 동정하였다. 동정된 균의 병원성을 확인하기 위하여 PCR로 1 개의 구토독소 $(c e r)$ 와 5 개의 장독소 $(h b l C$, $b c e \mathrm{~T}, n h e \mathrm{~A}, e n t \mathrm{FM}, c y t \mathrm{~K})$ 유전자를 확인하여 한 개 이상의 유 전자를 가진 균주로 최종 진단하였다. L. monocytogenes는 검 체를 Oxford 선택배지에 접종하여 $37^{\circ} \mathrm{C}$ 에서 24시간 배양하여 검은색 집락을 선택하여 API Listeria kit (bioMerieux)를 이용 하여 동정하였다. Y. enterocolitica는 검체를 Cefsulodin Iragasan Novobiocin $(\mathrm{CIN})$ 에 $30^{\circ} \mathrm{C}, 18-24$ 시간 배양한 후, 중심부가 짙 은 적색을 띠며 주변 부위는 투명한 집락을 선별하여 TSA에 계대배양한 후, API 20E kit (bioMerieux)를 이용하여 최종 동 정하였다.

\section{RESULTS}

\section{1. 원인 병원성 세균 분리율}

2012년 급성설사질환 실험실 감시사업을 통해 전국적으로 총 21,180 건의 설사환자에서 수집된 분변 검체를 대상으로 검 사한 결과, 감시대상 병원체가 확인된 검체는 전체 검체의 $11.5 \%$ 인 2,444건으로 Salmonella spp. 415건(17\%), 전체 양성 검체의 $30.1 \%$ 를 차지하는 E. coli 750 건(EPEC $64.5 \%$, EAEC $16.8 \%$, ETEC 13.3\%, EHEC 4.9\%, EIEC 0.4\%), V. parahaemolyticus 23건(0.9\%), Shigella spp. 9건(0.4\%), Campylobacter spp. 141건(5.8\%), C. perfringens 97건(4.0\%), S. aureus 832건 (34.0\%), B. cereus 173건(7.1\%), L. monocytogenes 1건(0.04\%), Y. enterocolitica 3 건 $(0.12 \%)$ 이 분리되었다. 또한 검사 결과, 한 환자에서 중복 감염된 경우는 137 건( $0.65 \%)$ 이었다. 단, 결과 분 석에 오차를 줄 수 있는 식중독 집단발생이나, 바이러스 등 감 시 대상이 아닌 병원체가 확인된 경우는 결과 산출에서 제외하 였다.

\section{2. 월별 병원성 세균 분리율}

월별 병원체 분리율은 하절기에 해당하는 6 월부터 9월에 분 
리율이 높았고, 10 월까지 지속되었으며, 평균 분리율은 8 월에 $25.9 \%$ 로 가장 높은 분리율을 보였다. 병원체별로는 Salmonella $\mathrm{spp}$.는 하절기의 시작과 끝에 해당되는 6월과 9월에 분리율이 급증하는 경향을 보였다. S. Enteritidis와 $S$. Typhimurium은 4-10월에 증가하였고, 기타 혈청형의 분리율이 증가하여 전체 적으로 하절기에 다양한 혈청형별이 분리되는 경향을 보였다. 하절기에 집중적으로 발생하던 Pathogenic E. coli는 12월까지 지속적으로 분리되었으며, 장독소성 대장균(ETEC)과 장병원 성 대장균(EPEC), 장출혈성 대장균(EHEC), 그리고 장흡착성 대장균(EAEC)의 경우 하절기인 7-9월에 주로 분리되는 계절성 을 보였으나 전체적으로 연중 지속적으로 분리되는 경향을 보 였다. V. parahaemolyticus는 8월, 9월에 증가하여 11월에도 분 리가 되었으며, Shigella spp.는 연중 산발적으로 9건 발생하였 다. Campylobacter spp.는 연중 분리되는 경향을 보였으며 3-8 월에 주로 분리되었다(Table 1).

2012년부터 대상병원체로 포함된 추가 5종의 세균에 대한 분리율은 C. perfringens, S. aureus, B. cereus는 연중 고르게 분 리되는 경향을 보였다.

\section{3. 연령별 병원성 세균의 분리율}

연령별 병원성 세균의 분리율은 0-9세의 어린이와 50대에서 높은 비율을 차지하고 있었다(Table 2), 취학 전 어린이에게서
분리율이 높은 것은 영유아의 면역성이 아직 낮은 점과 단체 급식과도 관계가 있을 것으로 판단된다. 병원체별로는 S. aureus와 Pathogenic E. coli는 10세 이하의 어린이 연령층에서 높 은 분리율을 보였으며, Salmonella spp.와 B. cereus 역시 10세 이하의 어린이 연령층에서 높은 분리율을 보였다.

성별로는 남성 1,135명(46.4\%)으로 여성 959명(39.2\%)보다 높았다. 성별에 따른 세균성 병원체의 분리율은 환자의 성비와 검체수를 비교해 보았을 때 전체적으로는 남녀 간의 유의적인 차이점은 찾을 수 없었다(자료 미제시).

\section{4. 지역별 병원체 분리율}

지역별로 구분하였을 경우, Salmonella spp.는 제주, 인천, 광 주 그리고 대구지역에서 전반적으로 분리율이 높았다. $S$. Typhimurium은 제주와 인천지역에서 많이 분리되었고, $S$. Enteritidis는 제주와 대전 그리고 광주지역에서 많이 분리되었 다. 특히, 제주지역에서는 S. Enteritidis에 의한 발생이 많아 Salmonella spp.의 분리율이 상대적으로 높았다. 기타 Salmonella 균주는 229균주로 55.2\%를 차지하며, 인천, 광주, 대구 그 리고 제주지역에서 많이 분리되었다. ETEC 분리율은 $13.3 \%$ 로 경남, 광주지역에서 많이 분리되었으며, 특히 경남지역에서는 $\mathrm{ETEC}$ 분리의 집중현상이 있었다. $\mathrm{EPEC}$ 는 광주와 대전, 그리 고 대구지역에서 많이 분리되었다. 전체원인병원체의 $5.8 \%$ 를

Table 1. Monthly isolation rate of bacterial pathogens isolated in Korea, 2012

\begin{tabular}{|c|c|c|c|c|c|c|c|c|c|c|c|c|c|}
\hline Pathogens & Jan. & Feb. & Mar. & Apr. & May & Jun. & Jul. & Aug. & Sep. & Oct. & Nov. & Dec. & Sum \\
\hline \multicolumn{14}{|l|}{ Salmonella } \\
\hline Enteritidis & 12 & 6 & 2 & 18 & 10 & 13 & 15 & 15 & 22 & 13 & 8 & 3 & 137 \\
\hline Typhimurium & 3 & 0 & 0 & 8 & 3 & 7 & 7 & 1 & 7 & 7 & 2 & 4 & 49 \\
\hline Others & 16 & 6 & 6 & 15 & 19 & 21 & 29 & 27 & 42 & 26 & 15 & 7 & 229 \\
\hline Total & 31 & 12 & 8 & 41 & 32 & 41 & 51 & 43 & 71 & 46 & 25 & 14 & 415 \\
\hline \multicolumn{14}{|l|}{ E. coli } \\
\hline EHEC & 3 & 1 & 1 & 1 & 0 & 4 & 14 & 5 & 2 & 4 & 2 & 0 & 37 \\
\hline ETEC & 1 & 2 & 3 & 0 & 6 & 9 & 22 & 24 & 20 & 5 & 1 & 7 & 100 \\
\hline EAEC & 1 & 2 & 5 & 8 & 4 & 3 & 16 & 23 & 26 & 10 & 18 & 10 & 126 \\
\hline EPEC & 21 & 13 & 16 & 20 & 25 & 52 & 81 & 73 & 73 & 54 & 33 & 23 & 484 \\
\hline EIEC & 0 & 0 & 0 & 0 & 0 & 1 & 0 & 0 & 0 & 1 & 1 & 0 & 3 \\
\hline Total & 26 & 18 & 25 & 29 & 35 & 69 & 133 & 125 & 121 & 74 & 55 & 40 & 750 \\
\hline Vibrio parahaemolyticus & 0 & 0 & 0 & 0 & 0 & 0 & 1 & 11 & 8 & 2 & 1 & 0 & 23 \\
\hline Shigella spp. & 0 & 0 & 1 & 0 & 1 & 0 & 2 & 0 & 0 & 2 & 3 & 0 & 9 \\
\hline Campylobacter spp. & 10 & 9 & 14 & 8 & 13 & 26 & 27 & 19 & 6 & 0 & 3 & 6 & 141 \\
\hline Clostridium perfringens & 9 & 8 & 11 & 13 & 12 & 11 & 11 & 2 & 4 & 3 & 4 & 9 & 97 \\
\hline Staphylococcus aureus & 67 & 67 & 74 & 92 & 73 & 60 & 71 & 48 & 65 & 63 & 60 & 92 & 832 \\
\hline Bacillus cereus & 6 & 3 & 16 & 26 & 9 & 14 & 23 & 18 & 21 & 16 & 12 & 9 & 173 \\
\hline Listeria monocytogens & 1 & 0 & 0 & 0 & 0 & 0 & 0 & 0 & 0 & 0 & 0 & 0 & 1 \\
\hline Yersinia enterocolitica & 1 & 0 & 0 & 0 & 0 & 0 & 0 & 1 & 1 & 0 & 0 & 0 & 3 \\
\hline No. of isolation & 151 & 117 & 149 & 209 & 175 & 221 & 319 & 267 & 297 & 206 & 163 & 170 & 2,444 \\
\hline No. of specimens & 2,244 & 1,634 & 1,778 & 2,131 & 1,579 & 1,541 & 2,065 & 1,681 & 1,904 & 1,534 & 1,585 & 1,504 & 21,180 \\
\hline Isolation rate $(\%)$ & 6.7 & 7.2 & 8.4 & 9.8 & 11.1 & 14.3 & 15.4 & 15.9 & 15.6 & 13.4 & 10.3 & 11.3 & 11.5 \\
\hline
\end{tabular}

Abbreviations: EHEC, Enterohaemorrhagei E. coli; ETEC, Enterotoxigenic E.coli; EAEC, Enteroaggregative E.coli; EPEC, Enteropathogenic E. coli; EIEC, Enteroinvasive E. coli. 
Table 2. Distribution of reported cases of pathogens by sex and age in Korea, 2012

\begin{tabular}{|c|c|c|c|c|c|c|c|c|c|c|c|}
\hline & $\begin{array}{l}\text { No. }(\%) \\
(n=2,444)\end{array}$ & $\begin{array}{c}\text { Salmonella } \\
\text { spp. } \\
(\mathrm{n}=415)\end{array}$ & $\begin{array}{c}\text { Pathogenic } \\
\text { E. coli } \\
(\mathrm{n}=750)\end{array}$ & $\begin{array}{c}\text { Shigella } \\
\text { spp. } \\
(\mathrm{n}=9)\end{array}$ & $\begin{array}{c}\text { Vibrio } \\
\text { parahaem- } \\
\text { olyticus } \\
(\mathrm{n}=23)\end{array}$ & $\begin{array}{l}\text { Campylob- } \\
\text { acter spp. } \\
(\mathrm{n}=141)\end{array}$ & $\begin{array}{l}\text { C. perfri- } \\
\text { ngenes } \\
(\mathrm{n}=97)\end{array}$ & $\begin{array}{c}\text { S. aureus } \\
(\mathrm{n}=832)\end{array}$ & $\begin{array}{c}\text { B. cereus } \\
(\mathrm{n}=173)\end{array}$ & $\begin{array}{l}\text { L. mono- } \\
\text { cytogenes } \\
\quad(\mathrm{n}=1)\end{array}$ & $\begin{array}{l}Y . \text { entero- } \\
\text { colitica } \\
(\mathrm{n}=3)\end{array}$ \\
\hline \multicolumn{12}{|l|}{ Sex } \\
\hline Male & $\begin{array}{l}1,135 \\
(46.4)\end{array}$ & $\begin{array}{c}151 \\
(13.3)\end{array}$ & $\begin{array}{c}370 \\
(32.6)\end{array}$ & $\begin{array}{c}5 \\
(0.4)\end{array}$ & $\begin{array}{c}9 \\
(0.8)\end{array}$ & $\begin{array}{c}60 \\
(5.3)\end{array}$ & $\begin{array}{c}43 \\
(3.8)\end{array}$ & $\begin{array}{c}414 \\
(35.5)\end{array}$ & $\begin{array}{c}81 \\
(7.1)\end{array}$ & $\begin{array}{c}1 \\
(0.1)\end{array}$ & $\begin{array}{c}1 \\
(0.1)\end{array}$ \\
\hline Female & $\begin{array}{c}959 \\
(39.2)\end{array}$ & $\begin{array}{c}134 \\
(14.0)\end{array}$ & $\begin{array}{c}278 \\
(29.0)\end{array}$ & $\begin{array}{c}4 \\
(0.4)\end{array}$ & $\begin{array}{c}13 \\
(1.4)\end{array}$ & $\begin{array}{c}66 \\
(6.9)\end{array}$ & $\begin{array}{c}43 \\
(4.5)\end{array}$ & $\begin{array}{c}342 \\
(35.7)\end{array}$ & $\begin{array}{c}78 \\
(8.1)\end{array}$ & $\begin{array}{c}0 \\
(0)\end{array}$ & $\begin{array}{c}1 \\
(0.1)\end{array}$ \\
\hline Unknown & $\begin{array}{c}350 \\
(14.3)\end{array}$ & $\begin{array}{c}130 \\
(37.1)\end{array}$ & $\begin{array}{c}102 \\
(29.1)\end{array}$ & $\begin{array}{c}0 \\
(0)\end{array}$ & $\begin{array}{c}1 \\
(0.3)\end{array}$ & $\begin{array}{c}15 \\
(4.3)\end{array}$ & $\begin{array}{c}11 \\
(3.1)\end{array}$ & $\begin{array}{c}76 \\
(21.7)\end{array}$ & $\begin{array}{c}14 \\
(4.0)\end{array}$ & $\begin{array}{c}0 \\
(0)\end{array}$ & $\begin{array}{c}1 \\
(0.3)\end{array}$ \\
\hline \multicolumn{12}{|l|}{ Age } \\
\hline $0-9$ & $\begin{array}{l}1,262 \\
(51.6)\end{array}$ & $\begin{array}{c}180 \\
(14.3)\end{array}$ & $\begin{array}{c}358 \\
(28.4)\end{array}$ & $\begin{array}{c}3 \\
(0.2)\end{array}$ & $\begin{array}{c}0 \\
(0)\end{array}$ & $\begin{array}{c}52 \\
(4.1)\end{array}$ & $\begin{array}{c}25 \\
(2.0)\end{array}$ & $\begin{array}{c}535 \\
(42.4)\end{array}$ & $\begin{array}{c}107 \\
(8.5)\end{array}$ & $\begin{array}{c}1 \\
(0.1)\end{array}$ & $\begin{array}{c}1 \\
(0.1)\end{array}$ \\
\hline $10-19$ & $\begin{array}{c}136 \\
(5.6)\end{array}$ & $\begin{array}{c}22 \\
(16.2)\end{array}$ & $\begin{array}{c}41 \\
(30.1)\end{array}$ & $\begin{array}{c}1 \\
(0.7)\end{array}$ & $\begin{array}{c}1 \\
(0.7)\end{array}$ & $\begin{array}{c}24 \\
(17.6)\end{array}$ & $\begin{array}{c}9 \\
(6.6)\end{array}$ & $\begin{array}{c}28 \\
(20.6)\end{array}$ & $\begin{array}{c}10 \\
(7.4)\end{array}$ & $\begin{array}{c}0 \\
(0)\end{array}$ & $\begin{array}{c}0 \\
(0)\end{array}$ \\
\hline $20-29$ & $\begin{array}{c}63 \\
(2.6)\end{array}$ & $\begin{array}{c}6 \\
(9.5)\end{array}$ & $\begin{array}{c}14 \\
(22.2)\end{array}$ & $\begin{array}{c}2 \\
(3.2)\end{array}$ & $\begin{array}{c}3 \\
(4.8)\end{array}$ & $\begin{array}{c}18 \\
(28.6)\end{array}$ & $\begin{array}{c}2 \\
(3.2)\end{array}$ & $\begin{array}{c}13 \\
(20.6)\end{array}$ & $\begin{array}{c}5 \\
(7.9)\end{array}$ & $\begin{array}{c}0 \\
(0)\end{array}$ & $\begin{array}{c}0 \\
(0)\end{array}$ \\
\hline $30-39$ & $\begin{array}{c}75 \\
(3.1)\end{array}$ & $\begin{array}{c}9 \\
(12.0)\end{array}$ & $\begin{array}{c}33 \\
(44.0)\end{array}$ & $\begin{array}{c}0 \\
(0)\end{array}$ & $\begin{array}{c}5 \\
(6.7)\end{array}$ & $\begin{array}{c}8 \\
(10.7)\end{array}$ & $\begin{array}{c}5 \\
(6.7)\end{array}$ & $\begin{array}{c}15 \\
(20.0)\end{array}$ & $\begin{array}{c}0 \\
(0)\end{array}$ & $\begin{array}{c}0 \\
(0)\end{array}$ & $\begin{array}{c}0 \\
(0)\end{array}$ \\
\hline $40-49$ & $\begin{array}{c}92 \\
(3.8)\end{array}$ & $\begin{array}{c}15 \\
(16.3)\end{array}$ & $\begin{array}{c}38 \\
(41.3)\end{array}$ & $\begin{array}{c}0 \\
(0)\end{array}$ & $\begin{array}{c}1 \\
(1.1)\end{array}$ & $\begin{array}{c}4 \\
(4.3)\end{array}$ & $\begin{array}{c}2 \\
(2.2)\end{array}$ & $\begin{array}{c}29 \\
(31.5)\end{array}$ & $\begin{array}{c}3 \\
(3.3)\end{array}$ & $\begin{array}{c}0 \\
(0)\end{array}$ & $\begin{array}{c}0 \\
(0)\end{array}$ \\
\hline $50-59$ & $\begin{array}{c}183 \\
(7.5)\end{array}$ & $\begin{array}{c}17 \\
(9.3)\end{array}$ & $\begin{array}{c}78 \\
(42.6)\end{array}$ & $\begin{array}{c}1 \\
(0.5)\end{array}$ & $\begin{array}{c}8 \\
(4.4)\end{array}$ & $\begin{array}{c}8 \\
(4.4)\end{array}$ & $\begin{array}{c}9 \\
(4.9)\end{array}$ & $\begin{array}{c}49 \\
(26.8)\end{array}$ & $\begin{array}{c}12 \\
(6.6)\end{array}$ & $\begin{array}{c}0 \\
(0)\end{array}$ & $\begin{array}{c}1 \\
(0.5)\end{array}$ \\
\hline $60-69$ & $\begin{array}{c}111 \\
(4.5)\end{array}$ & $\begin{array}{c}20 \\
(18.0)\end{array}$ & $\begin{array}{c}33 \\
(29.7)\end{array}$ & $\begin{array}{c}0 \\
(0)\end{array}$ & $\begin{array}{c}1 \\
(0.9)\end{array}$ & $\begin{array}{c}7 \\
(6.3)\end{array}$ & $\begin{array}{c}10 \\
(9.0)\end{array}$ & $\begin{array}{c}28 \\
(25.2)\end{array}$ & $\begin{array}{c}12 \\
(10.8)\end{array}$ & $\begin{array}{c}0 \\
(0)\end{array}$ & $\begin{array}{c}0 \\
(0)\end{array}$ \\
\hline Over 70 & $\begin{array}{c}163 \\
(6.7)\end{array}$ & $\begin{array}{c}13 \\
(8.0)\end{array}$ & $\begin{array}{c}45 \\
(27.6)\end{array}$ & $\begin{array}{c}2 \\
(1.2)\end{array}$ & $\begin{array}{c}3 \\
(1.8)\end{array}$ & $\begin{array}{c}5 \\
(3.1)\end{array}$ & $\begin{array}{c}25 \\
(15.3)\end{array}$ & $\begin{array}{c}61 \\
(37.4)\end{array}$ & $\begin{array}{c}9 \\
(5.5)\end{array}$ & $\begin{array}{c}0 \\
(0)\end{array}$ & $\begin{array}{c}0 \\
(0)\end{array}$ \\
\hline Unknown & $\begin{array}{c}359 \\
(14.7)\end{array}$ & $\begin{array}{c}133 \\
(37.0)\end{array}$ & $\begin{array}{c}110 \\
(30.6)\end{array}$ & $\begin{array}{c}0 \\
(0)\end{array}$ & $\begin{array}{c}1 \\
(0.3)\end{array}$ & $\begin{array}{c}15 \\
(4.2)\end{array}$ & $\begin{array}{c}10 \\
(2.8)\end{array}$ & $\begin{array}{c}74 \\
(20.6)\end{array}$ & $\begin{array}{c}15 \\
(4.2)\end{array}$ & $\begin{array}{c}0 \\
(0)\end{array}$ & $\begin{array}{c}1 \\
(0.3)\end{array}$ \\
\hline
\end{tabular}

차지하는 Campylobacter spp.는 인천, 광주지역에서 많이 분리 되었다. V. parahaemolyticus는 경남과 전북지역에서 주로 분리 되었으며, Shigella spp.는 광주와 경남, 그리고 제주지역에서 주로 분리되었다. C. perfringens는 충남과 전북, 그리고 인천지 역에서 주로 분리되었고, S. aureus는 인천과 광주, 그리고 전남 지역에서 주로 분리되었으며, B. cereus는 주로 대구와 인천, 그 리고 광주지역에서 분리되었다. 전체 원인병원체 중에서 가장 적은 비율을 차지하는 L. monocytogenes의 경우 인천에서 1건 분리되었으며, Y. enterocolitica의 경우 인천과 광주, 경기지역 에서 각 1 건씩 분리되었다(Table 3 ).

\section{DISCUSSION}

매년 현저한 증가추세를 보이고 있는 설사질환은 전 세계적 으로 주요한 관심의 대상이 되고 있다[10]. 세균성 설사의 원인 으로는 E. coli O157, Salmonella spp., Shigella spp., Vibrio cholera, Vibrio parahaemolyticus, Campylobacter spp., Staphylococcus aureus, Yersinia enterocolitica, Listeria monocytogenes 등이 주요한 병원체이다[11-13].

이번 연구에서 2012년도 감시사업 결과는 2011년도의 양성
검체 1,338 건, 양성률 $3.46 \%$ 와 비교할 때[14], 양성 검체수와 양성률이 상당히 증가하였다. 이는 2008년도부터 2011년도까 지의 감시사업에서는 감시대상 병원체가 Salmonella spp., pathogenic E. coli, Shigella spp., V. parahaemolyticus, Campylobacter spp. 등 세균 5종을 대상으로 하였으나, 세균 10종을 대상으로 한 2012년도에는 장내 상재균인 S. aureus와 영·유아에 있어 미량으로도 감염이 가능한 설사유발균인 $\mathrm{EPEC}$ 의 분리율 증가 로 인해 상대적으로 병원성 세균의 검출률이 높아졌기 때문이다.

또한 pathogenic E. coli의 경우 2012년도 이전에는 EHEC와 $\mathrm{ETEC}$ 만을 감시대상 병원체로 포함시켰으나 2012년도에는 병 원성 대장균 $\mathrm{EPEC}, \mathrm{EAEC}, \mathrm{EIEC}$ 를 포함하여 총 5종으로 감시 대상 병원체를 확대하여 분리건수가 상대적으로 2011년도에 비해 2012년도에 증가하였다. EHEC와 ETEC만을 포함한 2011 년도 병원성 대장균의 경우 148 건 분리되었으나, 2012년도에 는 5종의 pathogenic E. coli를 검출할 수 있게 되었기 때문에 750 건 검출할 수 있었고, 5 배 이상 분리건수가 증가함을 나타 내었다.

선진국과 후진국을 불문하고 꾸준하게 보고되고 있는 Salmonella spp.는 $S$. Typhi에서 $S$. Enteritidis로 유행이 변화하고 있는데[15], 이번 감시사업 결과도 $S$. Enteritidis의 분리율이 
Table 3. Regional distribution of pathogens isolated in Korea, 2012

\begin{tabular}{|c|c|c|c|c|c|c|c|c|}
\hline \multirow{2}{*}{ Region } & \multicolumn{3}{|c|}{ Salmonella } & \multicolumn{5}{|c|}{ Escherichia coli } \\
\hline & $\begin{array}{l}\text { Enteritidis } \\
\text { No }(\%)\end{array}$ & $\begin{array}{l}\text { Typhimurium } \\
\text { No (\%) }\end{array}$ & $\begin{array}{l}\text { Others } \\
\text { No }(\%)\end{array}$ & $\begin{array}{c}\text { EHEC } \\
\text { No }(\%)\end{array}$ & $\begin{array}{c}\text { ETEC } \\
\text { No }(\%)\end{array}$ & $\begin{array}{c}\text { EAEC } \\
\text { No }(\%)\end{array}$ & $\begin{array}{c}\text { EPEC } \\
\text { No }(\%)\end{array}$ & $\begin{array}{c}\text { EIEC } \\
\text { No }(\%)\end{array}$ \\
\hline Seoul & $2(1.5)$ & $0(0)$ & $4(1.7)$ & $1(2.7)$ & $3(3.0)$ & $11(8.7)$ & $29(6.0)$ & $0(0)$ \\
\hline Busan & $9(6.6)$ & $4(8.2)$ & $16(7.0)$ & $0(0)$ & $5(5.0)$ & $17(13.5)$ & $16(3.3)$ & $0(0)$ \\
\hline Daegu & $14(10.2)$ & $3(6.1)$ & $26(11.4)$ & 8 (21.6) & $4(4.0)$ & $0(0)$ & 56 (11.6) & $0(0)$ \\
\hline Incheon & $9(6.6)$ & 7 (14.3) & $46(20.1)$ & $0(0)$ & $5(5.0)$ & 15 (11.9) & $40(8.3)$ & $1(33.3)$ \\
\hline Gwangju & $17(12.4)$ & $4(8.2)$ & 37 (16.2) & $9(24.3)$ & $9(9.0)$ & $32(25.4)$ & 93 (19.2) & $0(0)$ \\
\hline Daejeon & $17(12.4)$ & $7(14.3)$ & $19(8.3)$ & 7 (18.9) & $5(5.0)$ & $0(0)$ & 93 (19.2) & $0(0)$ \\
\hline Ulsan & $0(0)$ & $2(4.1)$ & $3(1.3)$ & $2(5.4)$ & $1(1.0)$ & $12(9.5)$ & $13(2.7)$ & $1(33.3)$ \\
\hline Gyeonggi & $0(0)$ & $2(4.1)$ & $5(2.2)$ & $0(0)$ & $6(6.0)$ & $3(2.4)$ & 31 (6.4) & $1(33.3)$ \\
\hline Gangwon & $4(2.9)$ & $2(4.1)$ & $5(2.2)$ & $1(2.7)$ & $0(0)$ & $4(3.2)$ & $3(0.6)$ & $0(0)$ \\
\hline Chungnam & $4(2.9)$ & $0(0)$ & $3(1.3)$ & $2(5.4)$ & $4(4.0)$ & $13(10.3)$ & $29(6.0)$ & $0(0)$ \\
\hline Chungbuk & $1(0.7)$ & $0(0)$ & $2(0.9)$ & $0(0)$ & $5(5.0)$ & $1(0.8)$ & $8(1.7)$ & $0(0)$ \\
\hline Jeonnam & $5(3.6)$ & $3(6.1)$ & $6(2.6)$ & $3(8.1)$ & $4(4.0)$ & $2(1.6)$ & $13(2.7)$ & $0(0)$ \\
\hline Jeonbuk & $1(0.7)$ & $2(4.1)$ & $10(4.4)$ & $2(5.4)$ & $7(7.0)$ & $0(0)$ & $23(4.8)$ & $0(0)$ \\
\hline Gyeongnam & $7(5.1)$ & $1(2.0)$ & $11(4.8)$ & $2(5.4)$ & $42(42.0)$ & $16(12.7)$ & $31(6.4)$ & $0(0)$ \\
\hline Gyeongbuk & $11(8.0)$ & $2(4.1)$ & $10(4.4)$ & $0(0)$ & $0(0)$ & $0(0)$ & $2(0.4)$ & $0(0)$ \\
\hline Jeju & $36(26.3)$ & $10(20.4)$ & $26(11.4)$ & $0(0)$ & $0(0)$ & $0(0)$ & $1(0.2)$ & $0(0)$ \\
\hline Total & $137(100)$ & 49 (100) & $229(100)$ & $37(100)$ & $100(100)$ & $126(100)$ & $484(100)$ & $3(100)$ \\
\hline Region & $\begin{array}{c}\text { Shigella spp. } \\
\text { No }(\%)\end{array}$ & $\begin{array}{c}\text { Vibrio. } \\
\text { Parahaemolyticus } \\
\text { No }(\%)\end{array}$ & $\begin{array}{c}\text { Campylo } \\
\text { bacter spp. } \\
\text { No }(\%)\end{array}$ & $\begin{array}{c}\text { C. } \\
\text { perfringenes } \\
\text { No }(\%)\end{array}$ & $\begin{array}{l}\text { S. aureus } \\
\text { No }(\%)\end{array}$ & $\begin{array}{l}\text { B. cereus } \\
\text { No }(\%)\end{array}$ & $\begin{array}{c}\text { L. monocy } \\
\text { togenes } \\
\text { No }(\%)\end{array}$ & $\begin{array}{l}Y . \text { enter } \\
\text { ocolitica } \\
\text { No }(\%)\end{array}$ \\
\hline Seoul & $0(0)$ & $1(4.3)$ & $9(6.4)$ & $2(2.1)$ & $64(7.7)$ & $6(3.5)$ & $0(0)$ & $0(0)$ \\
\hline Busan & $0(0)$ & $0(0)$ & $4(2.8)$ & $4(4.1)$ & $33(4.0)$ & $1(0.6)$ & $0(0)$ & $0(0)$ \\
\hline Daegu & $0(0)$ & $0(0)$ & $6(4.3)$ & $7(7.2)$ & $73(8.8)$ & $44(25.4)$ & $0(0)$ & $0(0)$ \\
\hline Incheon & 1 (11.1) & $1(4.3)$ & $40(28.4)$ & $12(12.4)$ & $209(25.1)$ & 27 (15.6) & $1(100)$ & $1(33.3)$ \\
\hline Gwangju & $2(22.2)$ & $0(0)$ & $31(22.0)$ & $4(4.1)$ & $171(20.6)$ & 27 (15.6) & $0(0)$ & $1(33.3)$ \\
\hline Daejeon & $0(0)$ & $0(0)$ & $7(5.0)$ & $1(1.0)$ & $40(4.8)$ & $5(2.9)$ & $0(0)$ & $0(0)$ \\
\hline Ulsan & $0(0)$ & $1(4.3)$ & $9(6.4)$ & $11(11.3)$ & $19(2.3)$ & $1(0.6)$ & $0(0)$ & $0(0)$ \\
\hline Gyeonggi & $0(0)$ & $1(4.3)$ & $1(0.7)$ & $2(2.1)$ & $22(2.6)$ & $6(3.5)$ & $0(0)$ & $1(33.3)$ \\
\hline Gangwon & $0(0)$ & $0(0)$ & $2(1.4)$ & $0(0)$ & $10(1.2)$ & $3(1.7)$ & $0(0)$ & $0(0)$ \\
\hline Chungnam & $1(11.1)$ & $3(13.0)$ & $5(3.5)$ & $24(24.7)$ & $23(2.8)$ & $10(5.8)$ & $0(0)$ & $0(0)$ \\
\hline Chungbuk & $0(0)$ & $1(4.3)$ & $3(2.1)$ & $1(1.0)$ & $0(0)$ & $0(0)$ & $0(0)$ & $0(0)$ \\
\hline Jeonnam & $1(11.1)$ & $2(8.7)$ & $1(0.7)$ & $7(7.2)$ & $100(12.0)$ & $12(6.9)$ & $0(0)$ & $0(0)$ \\
\hline Jeonbuk & $0(0)$ & $4(17.4)$ & $10(7.1)$ & $16(16.5)$ & $35(4.2)$ & $24(13.9)$ & $0(0)$ & $0(0)$ \\
\hline Gyeongnam & $2(22.2)$ & $8(34.8)$ & $5(3.5)$ & $4(4.1)$ & $30(3.6)$ & $4(2.3)$ & $0(0)$ & $0(0)$ \\
\hline Gyeongbuk & $0(0)$ & $0(0)$ & $0(0)$ & $0(0)$ & $0(0)$ & $1(0.6)$ & $0(0)$ & $0(0)$ \\
\hline Jeju & $2(22.2)$ & $1(4.3)$ & $8(5.7)$ & $2(2.1)$ & $3(0.4)$ & $2(1.2)$ & $0(0)$ & $0(0)$ \\
\hline Total & $9(100)$ & $23(100)$ & $141(100)$ & 97 (100) & $832(100)$ & $173(100)$ & $1(100)$ & $3(100)$ \\
\hline
\end{tabular}

Abbreviations: Chungnam, Chungcheongnam-do; Chungbuk, Chungcheongbuk-do; Jeonnam, Jeollanam-do; Jeonbuk, Jeonllabuk-do; Gyeongnam, Gyeongsangnam-do; Gyeongbuk, Gyeongsangbuk-do.

$33 \%$ 로 다른 Salmonella spp. 분리율보다 높았다. 성별, 연령별 Salmonella spp.의 분리율은 남성 $36 \%$ 와 여성 $32 \%$ 로 유의성은 없었고, 10 세 이하의 연령군(43\%)에서 높은 분리율을 보였는 데 이는 소아에서 세포 및 체액면역기전의 미숙과 장관의 정상 상재균이 미숙한 상태에서 분변에 의한 경구감염의 기회증가 등의 요인에 의한 것이라는 보고가 있다[16].

개발 도상국에서 설사질환으로 인한 사망원인의 $10 \%$ 를 차 지하는[17] Shigella spp.는 최근 S. sonnei에 의한 감염 및 집단 발생보고가 국내외에서 보고되고 있는데[18], 환경이나 개인위 생 수준이 높은 나라에서는 S. flexneri에 의한 감염은 감소하고
S. sonnei에 의한 감염은 증가하는 소견과 일치한다. 반면 이번 감시사업 결과 9 건의 분리된 Shigella spp.는 S. flexneri 4건, $S$. sonnei 2건, S. boydii 2건, S. dysenteriae 1건으로 균등하게 분 리되는 경향을 보였다.

어패류를 즐겨 생식하는 우리나라와 일본 등지에서 중요한 설사질환의 원인균으로 널리 알려진 $V$. parahaemolyticus는 해 수, 갯벌, 어패류에서 7월에 30\%의 분리율을 보였다[19-21]. 그 러나 감시사업의 결과는 V. parahaemolyticus는 8-9월에 집중적 으로 발생하였으며 50대의 연령층에서 주로 발병하였다.

Campylobacter spp.의 경우 캐나다에서 발표한 감시 자료 
(C-EnterNet)에 의하면 식중독균의 제 1 병원체로 캠필로박터균 (36\%)이 확인되었으며[22], 우리나라 감시사업의 결과도 마찬 가지로 Campylobacter spp.의 분리율이 매년 꾸준히 증가하고 있으며 선진국의 식중독 원인체 분리경향에 가까워지고 있다 [23].

$S$. aureus는 주위 환경에 널리 분포하는 병원성 세균으로 $34 \%$ 의 분리율을 차지하고 있으며 점차 증가하는 분리경향을 나타내는 것으로 보아, 실험실 감시사업에서 뿐만 아니라 결과 산출에서 제외한 집단 식중독 발생 원인균으로서의 중요성이 커지고 있다고 생각한다.

미국 $\mathrm{CDC}$ 에서는 2009년과 2010년 2년에 걸쳐 식품매개 질 환 집단발생에 대한 감시 사업을 실시한 결과, 바이러스와 원 충을 제외한 세균성 병원체에 의한 집단발생 사례는 전체 발생 의 $52 \%$ 에 해당하는 413 건이었으며, 이 중 Salmonella spp.는 확진 사례 234건으로 감시대상 병원체 중 가장 높은 분리율을 보였으며, Salmonella spp. 집단발생 확진 사례 225건 중 $S$. Enteritidis는 전체 사례의 $34 \%$ 로 가장 흔히 분리되는 혈청형이 었다[24]. 국내의 감시사업 결과에서도 다른 혈청형의 Salmonella spp. 분리율에 비해 S. Enteritidis가 차지하고 있는 비율이 증가함을 확인할 수 있었다.

세균은 일반적으로 고온 다습한 환경에서 왕성하게 성장하 여 질병을 유발하는 것으로 알려져 있으며, 하절기인 6월부터 9월에 집중적으로 질병을 유발한다. 그러나 최근 5년간의 감시 사업 결과를 보면 하절기의 고온 다습한 기상상태와 설사질환 발생이 반드시 일치하지만은 않는 것으로 나타났으며, 일부 병 원체는 하절기가 아닌 시기에도 설사를 유발하는 것을 확인할 수 있었다. 감시 사업 결과 S. aureus와 C. perfringens의 경우 연중 지속적으로 분리되었으며, Salmonella spp.는 하절기인 6 월부터 9월에 주로 분리되었고, 하절기에 집중 발생하던 pathogenic E. coli의 경우 12 월까지 지속적으로 분리되는 경향을 보 였다. V. parahaemolyticus는 8월과 9월에, Shigella spp.의 경우 7 월과 10 월, 그리고 11 월에 주로 분리되었으며, B. cereus는 4 월과 7월에, Campylobacter spp.는 7월부터 9월에 주로 분리되 었다. 대부분의 병원체는 주로 하절기에 집중 발생하는 경향을 보였으나 pathogenic E. coli와 S. aureus, 그리고 C. perfringens 의 경우 12 월까지 연중 지속적으로 분리되는 경향을 보아 우리 나라 기상 조건이 온대에서 아열대로의 변동에 따른 기후 변화 와 식생활의 변화, 조리 시설의 개선 등 환경적 요인에 의해 급 성 설사질환을 일으키는 병원성 세균의 분리 양상에 변화가 있 는 것으로 예상된다.

원인병원체의 연령별 발생현황은 주로 감염 취약계층인 0-9 세의 미취학아동과 저학년에서 전체 발생률의 절반이 넘었고, 이는 영유아의 면역성이 아직 제대로 갖추어지지 않았고 단체 급식과도 관계가 있을 것으로 판단된다. 다른 연령층에 비해 감염취약계층인 10 세 미만의 연령층과 50 대, 그리고 70 세 이상
의 노약계층에 대해 지속적인 개인위생 관리와 모니터링 강화 가 필요할 것으로 보인다.

급성설사질환을 예방하기 위하여 병·의원 및 각 시, 도 보건 환경연구원을 연계한 설사질환 감시사업을 지속적으로 실시함 으로써, 설사질환 유발 원인병원체에 대한 지속적인 자료의 축 적과 효율적인 정보를 파악할 수 있으며, 질병 관리 대책 수립 의 기초자료로서 향후 설사질환에 대한 적절한 공중보건학적 대응에 도움이 될 것으로 생각한다.

\section{ACKNOWLEDGMENTS}

이 연구는 2012년도 수인성 식품매개질환 실험실 감시사업 운영연구비(4800-4851-300-210) 지원에 의해 수행되었음.

\section{REFERENCES}

1. Flint JA, Van Duynhoven YT, Angulo FJ, DeLong SM, Braun P, Kirk M, et al. Estimating the burden of acute gastroenteritis, foodborne disease, and pathogens commonly transmitted by food: an international review. Clin Infect Dis 2005;41:698-704.

2. Havelaar AH, Cawthorne A, Angulo F, Bellinger D, Corrigan T, Cravioto A, et al. WHO initiative to estimate the global burden of foodborne diseases. The Lancet 2013;381:S59.

3. Mitsuda T. Infection prevention and control for foodborne infections. Nihon Rinsho 2012;70:1406-13.

4. Lahuerta A, Westrell T, Takklnen J, Boelaert F, Rizzi V, Helwigh $\mathrm{B}$, et al. Zoonoses in the European Union: origin, distribution and dynamics-the EFSA-ECDC summary report 2009. Euro Surveill 2011;16:5-8.

5. Kirk MD, McKay I, Hall GV, Dalton CB, Stafford R, Unicomb L, et al. Food safety: foodborne disease in Australia: the OzFoodNet experience. Clin Infect Dis 2008;47:392-400.

6. Kendall ME, Crim S, Fullerton K, Han PV, Cronquist AB, Shiferaw B, et al. Travel-associated enteric infections diagnosed after return to the United States, Foodborne Diseases Active Surveillance Network (FoodNet), 2004-2009. Clin Infect Dis 2012;54 Suppl 5:S480-7.

7. National Enteric Surveillance Program (NESP). Executive Summary for the National Enteric Surveillance Program 2011 Annual Report. https://www.nml-lnm.gc.ca/NESP-PNSME/surveillance-2011-eng. $\mathrm{html} /[$ Online] (last visited on 15 June 2013).

8. Korea Centers for Disease Control and Prevention. Guideline of National Institute of Health Diagnostic Laboratory; Disease-Specific Protocol. 3rd ed. 2005.

9. Korea Centers for Disease Control and Prevention. Antigenic Formulas of the Salmonella Serovars. 2007.

10. Nyachuba DG. Foodborne illness: is it on the rise? Nutr Rev 2010; 68:257-69.

11. Newell DG, Koopmans M, Verhoef L, Duizer E, Aidara-Kane A, Sprong H, et al. Food-borne diseases - the challenges of 20 years ago still persist while new ones continue to emerge. Int $\mathrm{J}$ Food Microbiol 2010;139 Suppl 1:S3-15.

12. Scallan E, Hoekstra RM, Angulo FJ, Tauxe RV, Widdowson MA, Roy SL, et al. Foodborne illness acquired in the United States-major pathogens. Emerg Infect Dis 2011;17:7-15. 
13. Potasman I, Paz A, Odeh M. Infectious outbreaks associated with bivalve shellfish consumption: a worldwide perspective. Clin Infect Dis 2002;35:921-8.

14. Korea Centers for Disease Control and Prevention. The prevalence and characteristics of bacteria causing acute diarrhea in Korea, 2011. PHWR 2013;6:345-50.

15. Rodrigue DC, Tauxe RV, Rowe B. International increase in Salmonella enteritidis: a new pandemic? Epidemiol Infect 1990; 105:21-7.

16. Agunod M, Yamaguchi N, Lopez R, Luhby AL, Glass GB. Correlative study of hydrochloric acid, pepsin, and intrinsic factor secretion in newborns and infants. Am J Dig Dis 1969;14:400-14.

17. Kotloff KL, Winickoff JP, Ivanoff B, Clemens JD, Swerdlow DL, Sansonetti PJ, et al. Global burden of Shigella infections: implications for vaccine development and implementation of control strategies. Bull World Health Organ 1999;77:651-66.

18. Drews SJ, Lau C, Andersen M, Ferrato C, Simmonds K, Stafford $\mathrm{L}$, et al. Laboratory based surveillance of travel-related Shigella sonnei and Shigella flexneri in Alberta from 2002 to 2007. Global Health 2010;6:20.

19. Hara-Kudo Y, Saito S, Ohtsuka K, Yamasaki S, Yahiro S, Nishio
$\mathrm{T}$, et al. Characteristics of a sharp decrease in Vibrio parahaemolyticus infections and seafood contamination in Japan. Int $\mathrm{J}$ Food Microbiol 2012;157:95-101.

20. Cho SH, Kim JH, Kim JC, Shin HH, Kang YH, Lee BK. Surveillance of bacterial pathogens associated with acute diarrheal disease in the Republic of Korea during one year, 2003. J Microbiol 2006;44:327-35.

21. Kubota K, Iwasaki E, Inagaki S, Nokubo T, Sakurai Y, Komatsu $\mathrm{M}$, et al. The human health burden of foodborne infections caused by Campylobacter, Salmonella, and Vibrio parahaemolyticus in Miyagi Prefecture, Japan. Foodborne Pathog Dis 2008;5:641-8.

22. Public Health Agency of Canada. C-EnterNet 2007 Annual Report. National Integrated Enteric Pathogen Surveillance Program, http:// www.phac-aspc.gc.ca/c-enternet/index.html/[Online] (last visited on 15 June 2013).

23. Cho SH, Shin HH, Choi YH, Park MS, Lee BK. Enteric bacteria isolated from acute diarrheal patients in the Republic of Korea between the year 2004 and 2006. J Microbiol 2008;46:325-30.

24. CDC Morbidity and Mortality Weekly Report. Surveillance for Foodborne Disease Outbreaks-United States, 2009-2010. MMWR 2013;62:41-7. 
=국문초록=

\section{2년도 우리나라 급성설사질환 유발 원인 세균의 분리현황 및 특성}

${ }^{1}$ 질병관리본부 국립보건연구원 감염병센터 수인성질환과, ${ }^{2}$ 한림대학교 의과대학 진단검사의학교실 김난옥 ${ }^{1}$, 차인준 $^{1}$, 김재석 $^{2}$, 정경태 $^{1}$, 강연호 $^{1}$, 홍사현 $^{1}$

배경: 기후 변화에 따라 병원성 세균에 의한 설사증이 다발하고 있으며, 생활환경변화에 따라 설사를 유발하는 원인체의 분리 양상 또한 변화하고 있다. 국내에서 발생하는 세균성 급성설사질환 유발 원인 병원체의 종류, 지역적 특성, 연령분 포, 계절적 발생특성 및 분리균의 특성 등을 조사 분석하여 국내 발생 설사질환을 감소시키기 위한 기초 자료로 활용하 고 국내 설사환자 병원체의 특성을 파악하고자 하였다.

방법: 2012년 1월부터 12월까지 엔터넷을 통해 접수된 설사환자 검체 21,180건을 대상으로 설사질환을 유발하는 것으로 알려진 각 균 속의 주요 분리지역 및 환자의 나이, 성별에 따라 분석하였으며, 각 균 속에 대한 병원체 동정은 국립보건 연구원에서 발간한 감염병 실험실진단(2005년)에 준하여 실험을 수행하였다.

결과: 전체 21,180 건의 검체 중 감시 대상 원인 병원체의 분리율은 2,444 건으로 전체 검체의 $11.5 \%$ 를 차지하였으며, 하절 기인 6월부터 9월에 집중적으로 발생하였으나 Pathogenic E. coli와 Staphylococcus aureus, 그리고 Clostridium perfringens의 경우 연중 지속적으로 분리되는 경향을 보였다. 연령별 분리율은 감염 취약계층인 10 세 이하의 어린이 연령층에서 전체 발생률의 절반이 넘는 분리율을 보였다.

결론: 다른 연령층에 비해 감염 취약계층인 10 세 이하의 연령층과 50 대, 그리고 70 대 이상의 노약계층에 대한 위생교육 및 지속적인 모니터링이 필요할 것으로 보인다. 그리고 대상 병원체에 대한 감염 예방을 위해 감시사업을 실시하여 지속 적으로 자료를 축적하여 급성설사질환의 예방에 활용해야 할 것으로 생각한다. [Ann Clin Microbiol 2013;16:174-181]

교신저자 : 홍사현, 363-951, 충북 청원군 오송읍 오송생명2로 187 질병관리본부 국립보건연구원 감염병센터 수인성질환과

Tel: 043-719-8115, Fax: 043-719-8149

E-mail: strepto13@hanmail.net 